\title{
The effect of weighted finger exercises on the grip strength and the level record for students of the Faculty of Physical Education, Minia University in the javelin throw competition
}

\section{*Dr/ Nahed Hadad Abd -El gawad Hassan}

Introduction :

Stated that training programs for the force, especially weight training, can not be dispensed with, which has become one of the main factors in the success of the player. In addition, Provided that the proper methods are followed in the development of weight programs to achieve the desired results (15:23).

In recent years, there has been a cognitive explosion in the field of force training. It has become common practice to use the term of force training, weight training and resistance training. These are all used to describe the type of exercise that requires the body's muscular to move against a type of resistance (1:65).

It was found that weighted fingers were used to improve performance in different professions such as typing and playing some musical instruments such as piano, guitar and oud.

Weighted fingers were also used as a method of training in basketball, as it increase and improve the level of correct shouting, as well as raising the level of dribbling and scrolling, multiply the strength of the fingers and wrist and palm rest in general and help the strength , flexibility and carrying the fingers, which leads to the improvement of these skills.

The use of weighted fingers as a method of training in basketball lead to increase and improve the proportion of correct shooting, as well as raise the level of dribbling and scrolling, double the strength of fingers, wrist and palm hand in general and help the strength Flexibility and bearing fingers which will improve these skills (4), and that after 3 months of weight training which indicated that the weighted fingers training increased the rate of grip strength about $2.1 \mathrm{~kg}$ between the elderly (3) . 
The training and adding rationed weights of the fingers can have a positive impact in improving and raising the strength of the fingers of the player and because of that the positive impact in improving the grip strength of javelin throw player and raise the level of performance, thus improving the level record.

\section{Methods:}

\section{Research Methodology :}

Eexperimental method using the experimental design of three experimental groups because it is suitable for the nature of the study.

\section{Subjects:}

The participants in this study are 24 students in the fourth year of the Department of Athletics in the Faculty of Physical Education Minia University for the academic year 2016/2017 (age: $21.41 \pm$ 0.67 years; height: $175.25 \pm$ $5.24 \mathrm{~cm}$; mass: $74.06 \pm 4.42 \mathrm{~kg}$ ; Right grip strength: $58.19 \pm$ $2.78 \mathrm{~kg}$;Left grip strength: $58.44 \pm 2.79 \mathrm{~kg}$; The level record for javelin throw 26.36 $\pm \quad 2.51 \mathrm{~m}) \quad$ Participate volunteers ,They were divided into three experimental groups of 8 students.

Experimental Procedures :
Students

were introduced to the required procedures and the strength of the right and left grip was measured by the dynamometer and measuring the level record of the javelin-throw competition according to the International law of Athletics, the intensive training program was implemented for 8 weeks during the special preparation period from 7/2/2016 to 3/4/2016 with three training units (Sunday, Tuesday and Thursday) each week for the members of the research sample with a total of 24 units which the most references agreed (5) (7) (8) (9) (10) (14) (strength ,power, speed, Agility, balance dynamic, flexibility dynamic, coordination). The difference was in the used weight as the first group was trained with weights in the fingers $(10 \mathrm{~g})$ While the second experimental group was trained in weight $(20 \mathrm{~g})$ and the third experimental group was trained with weight $(30 \mathrm{~g})$ for one finger. These weights were stamped with the fingers during the performance of the skill part of the javelin, the post measurements were made in the same conditions and 
procedures

of

pre

measurements.

Table (1)

Time distribution and percentages of special physical characteristics during the weeks of the training Weighted Finger Program

\begin{tabular}{|c|c|c|c|c|c|c|c|c|c|}
\hline \multirow{2}{*}{$\begin{array}{c}(\min --- \\
\%)\end{array}$} & \multirow{2}{*}{$\begin{array}{l}\text { Physical } \\
\text { capacity }\end{array}$} & \multicolumn{8}{|c|}{ Training weeks } \\
\hline & & 1 & 2 & 3 & 4 & 5 & 6 & 7 & 8 \\
\hline $\begin{array}{l}(92 \min \\
--10 \%) \\
\end{array}$ & Strength & 17 & 23 & 40 & 12 & - & - & - & - \\
\hline $\begin{array}{l}(275 \mathrm{~min} \\
--30 \%)\end{array}$ & Power & 75 & 75 & 45 & 30 & 30 & 20 & - & - \\
\hline $\begin{array}{c}(183 \min \\
--20 \%)\end{array}$ & Speed & 30 & 23 & 25 & 30 & 40 & 20 & - & 15 \\
\hline $\begin{array}{l}\text { (92min } \\
--10 \%)\end{array}$ & Agility & 24 & 17 & 10 & 20 & 10 & 11 & - & - \\
\hline $\begin{array}{l}\text { (92min } \\
--10 \%)\end{array}$ & $\begin{array}{c}\text { Flexibility } \\
\text { dynamic }\end{array}$ & 20 & 14 & 10 & 16 & 10 & 12 & 10 & - \\
\hline $\begin{array}{l}(92 \mathrm{~min} \\
--10 \%)\end{array}$ & $\begin{array}{l}\text { Balance } \\
\text { dynamic }\end{array}$ & 14 & 18 & 10 & 10 & 10 & 12 & 18 & - \\
\hline $\begin{array}{l}(92 \mathrm{~min} \\
--10 \%)\end{array}$ & Coordination & 20 & 10 & 10 & 12 & 10 & 10 & 20 & - \\
\hline \multirow{2}{*}{\multicolumn{2}{|c|}{ Total weeks (min---\%) }} & 200 & 180 & 150 & 130 & 110 & 85 & 48 & 15 \\
\hline & & $70 \%$ & $63 \%$ & $56 \%$ & $46 \%$ & $37 \%$ & $31 \%$ & $16 \%$ & $5 \%$ \\
\hline
\end{tabular}

\section{Table (2)}

Time distribution and percentages of skill preparation on the training Weighted Finger Program weeks

\begin{tabular}{|c|c|c|c|c|c|c|c|c|c|}
\hline \multirow{2}{*}{$(\min ---\%)$} & \multirow{2}{*}{$\begin{array}{c}\text { Technical } \\
\text { Performance }\end{array}$} & \multicolumn{8}{|c|}{ Training weeks } \\
\hline & & 1 & 2 & 3 & 4 & 5 & 6 & 7 & 8 \\
\hline $\begin{array}{l}(138 \mathrm{~min} \\
--10 \%)\end{array}$ & $\begin{array}{l}\text { Hold the } \\
\text { Javelin }\end{array}$ & 85 & 20 & 20 & 13 & - & - & - & - \\
\hline $\begin{array}{l}(551 \mathrm{~min} \\
--40 \%)\end{array}$ & $\begin{array}{l}\text { Approaching } \\
\text { and cross steps }\end{array}$ & - & 25 & 40 & 50 & 98 & 94 & 122 & 122 \\
\hline $\begin{array}{l}(688 \min \\
--50 \%)\end{array}$ & $\begin{array}{c}\text { Javelin } \\
\text { throwing and } \\
\text { follow-up }\end{array}$ & - & 60 & 60 & 92 & 92 & 91 & 130 & 163 \\
\hline \multirow{2}{*}{\multicolumn{2}{|c|}{ Total weeks (min---\%) }} & 85 & 105 & 120 & 155 & 190 & 185 & 252 & 285 \\
\hline & & $30 \%$ & $37 \%$ & $44 \%$ & $54 \%$ & $63 \%$ & $69 \%$ & $84 \%$ & $95 \%$ \\
\hline
\end{tabular}

Assiut Journal For Sport Science Arts 
Table (3)

The general structure of the training Weighted Finger Program 
Statistical analysis:

"Arithmetic mean- meanstandard deviation- torsion coefficient- flattening coefficient- one-way contrast analysis- non-barometric test Mann-Whitney- nonbarometric test Wilkinson- correlation

percentage

coefficientScheffe test", The researcher accepted the level of significance at the level (0.05) and used the program SPSS to calculate some statistical transactions.

\section{Results:}

\section{Table (4)}

The significance of the differences between the average of the pre and the post measurements for the first experimental group in measuring the grip strength and the level record of the throw javelin in the non-barometric Wilcoxon method $(n=8)$

\begin{tabular}{|c|c|c|c|c|c|c|c|c|c|c|c|}
\hline \multirow{2}{*}{\multicolumn{2}{|c|}{ Variables }} & \multirow{2}{*}{$\begin{array}{l}\text { Measurement } \\
\text { unit }\end{array}$} & \multicolumn{2}{|c|}{$\begin{array}{c}\text { Pre } \\
\text { measurement }\end{array}$} & \multicolumn{2}{|c|}{$\begin{array}{c}\text { Post } \\
\text { measurement }\end{array}$} & \multirow{2}{*}{$\begin{array}{c}\text { Grade } \\
\text { sum }\end{array}$} & \multirow{2}{*}{$\begin{array}{l}\text { Grade } \\
\text { average }\end{array}$} & \multirow{2}{*}{$\begin{array}{c}\text { Signal } \\
\text { direction }\end{array}$} & \multirow{2}{*}{$\mid \begin{array}{c}Z \\
\text { Value }\end{array}$} & \multirow{2}{*}{$\begin{array}{l}\text { Exchange } \\
\text { rate } \%\end{array}$} \\
\hline & & & Mean & \pm S.D & Mean & \pm S.D & & & & & \\
\hline \multirow{2}{*}{$\begin{array}{l}\text { Measuring } \\
\text { the grip } \\
\text { strength }\end{array}$} & $\begin{array}{l}\text { Right } \\
\text { grip } \\
\text { strength }\end{array}$ & $\mathrm{Kg}$ & 58.00 & 2.07 & 58.88 & 2.47 & $\begin{array}{l}4.00 \\
32.00\end{array}$ & $\begin{array}{l}4.00 \\
4.57\end{array}$ & $\begin{array}{l}-1 \\
+7 \\
=0\end{array}$ & -2.11 & 1.52 \\
\hline & $\begin{array}{c}\text { Left } \\
\text { grip } \\
\text { strength }\end{array}$ & $\mathrm{Kg}$ & 57.88 & 2.30 & 58.75 & 2.12 . & $\begin{array}{c}0.00 \\
28.00\end{array}$ & $\begin{array}{l}0.00 \\
4.00\end{array}$ & $\begin{array}{l}-0 \\
+7 \\
=1\end{array}$ & -2.65 & 1.50 \\
\hline \multicolumn{2}{|c|}{$\begin{array}{l}\text { The level record } \\
\text { of javelin throw }\end{array}$} & $\mathrm{M}$ & 25.24 & 1.95 & 25.54 & 1.85 & $\begin{array}{c}0.00 \\
36.00\end{array}$ & $\begin{array}{l}0.00 \\
4.50\end{array}$ & $\begin{array}{l}-0 \\
+8 \\
=0\end{array}$ & -2.52 & 1.19 \\
\hline
\end{tabular}

The value of tabled $(Z)$ at the level of significance $(0.05)=1.96$ Table (5)

The significance of the differences between the average of the pre and the post measurements for the second experimental group in measuring the grip strength and the level record of the throw javelin in the non-barometric Wilcoxon method $(n=8)$

\begin{tabular}{|c|c|c|c|c|c|c|c|c|c|c|c|}
\hline \multirow{2}{*}{\multicolumn{2}{|c|}{ Variables }} & \multirow{2}{*}{$\begin{array}{c}\text { Measurement } \\
\text { unit }\end{array}$} & \multicolumn{2}{|c|}{$\begin{array}{c}\text { Pre } \\
\text { measurement }\end{array}$} & \multicolumn{2}{|c|}{$\begin{array}{c}\text { Post } \\
\text { measurement }\end{array}$} & \multirow{2}{*}{$\begin{array}{c}\text { Grade } \\
\text { sum }\end{array}$} & \multirow{2}{*}{$\begin{array}{c}\text { Grade } \\
\text { average }\end{array}$} & \multirow{2}{*}{$\begin{array}{c}\text { Signal } \\
\text { direction }\end{array}$} & \multirow{2}{*}{$\begin{array}{c}Z \\
\text { value }\end{array}$} & \multirow{2}{*}{$\begin{array}{c}\text { Exchange } \\
\text { rate \% }\end{array}$} \\
\hline & & & Mean & \pm S.D & Mean & \pm S.D & & & & & \\
\hline \multirow{2}{*}{$\begin{array}{l}\text { Measuring } \\
\text { the grip } \\
\text { strength }\end{array}$} & $\begin{array}{l}\begin{array}{l}\text { Right grip } \\
\text { strength }\end{array} \\
\end{array}$ & $\mathrm{Kg}$ & 58.38 & 2.39 & 62.25 & 1.04 & $\begin{array}{c}0.00 \\
36.00\end{array}$ & $\begin{array}{l}0.00 \\
4.50\end{array}$ & $\begin{array}{l}0- \\
8+ \\
0=\end{array}$ & -2.54 & 6.63 \\
\hline & $\begin{array}{l}\text { Left } \\
\text { grip } \\
\text { strength }\end{array}$ & $\mathrm{Kg}$ & 59.75 & 1.91 & 62.00 & 1.93 & $\begin{array}{c}0.00 \\
36.00\end{array}$ & $\begin{array}{l}0.00 \\
4.50\end{array}$ & $\begin{array}{l}0- \\
8+ \\
0=\end{array}$ & -2.57 & 3.77 \\
\hline \multicolumn{2}{|c|}{$\begin{array}{l}\text { The level record } \\
\text { of javelin throw }\end{array}$} & $\mathrm{M}$ & 26.64 & 1.66 & 28.03 & 1.88 & $\begin{array}{c}0.00 \\
36.00\end{array}$ & $\begin{array}{l}0.00 \\
4.50\end{array}$ & $\begin{array}{l}0- \\
8+ \\
0=\end{array}$ & -2.52 & 5.22 \\
\hline
\end{tabular}

The value of tabled $(Z)$ at the level of significance $(0.05)=1.96$ 
Table (6)

The significance of the differences between the average of the pre and the post measurements for the third experimental group in measuring the grip strength and the level record of the throw javelin in the non-barometric Wilcoxon method $(n=8)$

\begin{tabular}{|c|c|c|c|c|c|c|c|c|c|c|c|}
\hline \multirow{2}{*}{\multicolumn{2}{|c|}{ Variables }} & \multirow[t]{2}{*}{$\begin{array}{c}\text { Measurement } \\
\text { Unit }\end{array}$} & \multicolumn{2}{|c|}{$\begin{array}{c}\text { Pre } \\
\text { measurement }\end{array}$} & \multicolumn{2}{|c|}{$\begin{array}{c}\text { Post } \\
\text { Measurement }\end{array}$} & \multirow[t]{2}{*}{$\begin{array}{l}\text { Grade } \\
\text { sum }\end{array}$} & \multirow[t]{2}{*}{$\begin{array}{c}\text { Grade } \\
\text { average }\end{array}$} & \multirow{2}{*}{$\begin{array}{c}\text { Signal } \\
\text { direction }\end{array}$} & \multirow[t]{2}{*}{$\begin{array}{c}\mathrm{Z} \\
\text { value }\end{array}$} & \multirow[t]{2}{*}{$\begin{array}{c}\text { Exchange } \\
\text { rate } \%\end{array}$} \\
\hline & & & Mean & \pm S.D & Mean & \pm S.D & & & & & \\
\hline \multirow{2}{*}{$\begin{array}{l}\text { Measuring } \\
\text { the grip } \\
\text { strength }\end{array}$} & $\begin{array}{l}\text { Right } \\
\text { grip } \\
\text { strength } \\
\end{array}$ & $\mathrm{Kg}$ & 58.25 & 3.20 & 65.50 & 2.83 & $\begin{array}{c}0.00 \\
36.00\end{array}$ & $\begin{array}{l}0.00 \\
4.50\end{array}$ & $\begin{array}{l}0- \\
8+ \\
0=\end{array}$ & -2.57 & 12.45 \\
\hline & $\begin{array}{l}\text { Left } \\
\text { grip } \\
\text { strength }\end{array}$ & $\mathrm{Kg}$ & 58.88 & 1.81 & 64.63 & 1.60 & $\begin{array}{c}0.00 \\
36.00\end{array}$ & $\begin{array}{l}0.00 \\
4.50\end{array}$ & $\begin{array}{l}0- \\
8+ \\
0=\end{array}$ & $\begin{array}{l}-2 . \\
64\end{array}$ & 9.77 \\
\hline \multicolumn{2}{|c|}{$\begin{array}{l}\text { The level record } \\
\text { of javelin throw }\end{array}$} & M & 26.78 & 1.59 & 30.45 & 1.32 & $\begin{array}{c}0.00 \\
36.00\end{array}$ & $\begin{array}{l}0.00 \\
4.50\end{array}$ & $\begin{array}{l}0- \\
8+ \\
0=\end{array}$ & -2.53 & 13.70 \\
\hline
\end{tabular}

The value of tabled $(Z)$ at the level of significance $(0.05)=1.96$

Table (7)

Analysis of the one-way variance between the post measurements for the three experimental groups In measuring the grip strength and the level record of javelin throw in question $(n 1=n 2=n 3=8)$

\begin{tabular}{|c|c|c|c|c|c|c|c|}
\hline \multicolumn{2}{|c|}{ Variables } & $\begin{array}{c}\text { Measurement } \\
\text { unit }\end{array}$ & $\begin{array}{l}\text { Variance } \\
\text { Source }\end{array}$ & $\begin{array}{c}\text { Freedom } \\
\text { degree }\end{array}$ & $\begin{array}{c}\text { Squares } \\
\text { sum }\end{array}$ & $\begin{array}{l}\text { Squares } \\
\text { Average }\end{array}$ & $\begin{array}{l}\text { Calculated } \\
\text { (F) value }\end{array}$ \\
\hline \multirow{4}{*}{$\begin{array}{l}\text { Measuring } \\
\text { the grip } \\
\text { strength }\end{array}$} & $\begin{array}{l}\text { Right } \\
\text { grip }\end{array}$ & $\mathrm{Kg}$ & $\begin{array}{c}\text { Between } \\
\text { groups }\end{array}$ & 175.58 & 2 & 87.79 & \multirow{2}{*}{17.35} \\
\hline & strength & & $\underset{\text { In }}{\text { In }}$ & 106.38 & 21 & 5.06 & \\
\hline & \multirow{2}{*}{$\begin{array}{c}\text { Left } \\
\text { grip } \\
\text { strength }\end{array}$} & \multirow[t]{2}{*}{$\mathrm{Kg}$} & $\begin{array}{c}\text { Between } \\
\text { groups }\end{array}$ & 138.58 & 2 & 69.29 & \multirow{2}{*}{19.30} \\
\hline & & & $\begin{array}{c}\text { In } \\
\text { groups }\end{array}$ & 75.38 & 21 & 3.59 & \\
\hline \multirow{2}{*}{\multicolumn{2}{|c|}{$\begin{array}{l}\text { The level record } \\
\text { of javelin throw }\end{array}$}} & M & $\begin{array}{c}\text { Between } \\
\text { groups }\end{array}$ & 96.44 & 2 & 48.22 & \multirow{2}{*}{16.63} \\
\hline & & & \begin{tabular}{|c|} 
In \\
groups
\end{tabular} & 60.89 & 21 & 2.90 & \\
\hline
\end{tabular}

The tabled (F) value at the degrees of freedom $(2,21)$ and the level of significance $(0.05)=3.47$ 
Table (8)

Schiffe test to indicate the differences between the averages of post measurements for the three experimental groups

\begin{tabular}{|c|c|c|c|c|c|c|c|}
\hline \multicolumn{2}{|l|}{ Variables } & $\begin{array}{l}\text { Measurement } \\
\text { unit }\end{array}$ & $\begin{array}{l}\text { The } \\
\text { groups }\end{array}$ & Mean & $\begin{array}{l}\text { The } \\
\text { first } \\
\text { group }\end{array}$ & $\begin{array}{l}\text { The } \\
\text { second } \\
\text { group }\end{array}$ & $\begin{array}{l}\text { The } \\
\text { third } \\
\text { group }\end{array}$ \\
\hline \multirow[t]{6}{*}{$\begin{array}{l}\text { Measuring } \\
\text { the grip } \\
\text { strength }\end{array}$} & \multirow{3}{*}{$\begin{array}{l}\text { Right } \\
\text { grip } \\
\text { strength }\end{array}$} & \multirow[t]{3}{*}{$\mathrm{Kg}$} & $\begin{array}{l}\text { First } \\
\text { group }\end{array}$ & 58.88 & & 3.37 & 6.62 \\
\hline & & & $\begin{array}{l}\text { Second } \\
\text { group }\end{array}$ & 62.25 & & & 3.25 \\
\hline & & & $\begin{array}{l}\text { Third } \\
\text { group }\end{array}$ & 65.50 & & & \\
\hline & \multirow{3}{*}{$\begin{array}{c}\text { Left } \\
\text { grip } \\
\text { strength }\end{array}$} & \multirow[t]{3}{*}{$\mathrm{Kg}$} & $\begin{array}{l}\text { First } \\
\text { group }\end{array}$ & 58.75 & & 3.25 & 5.88 \\
\hline & & & $\begin{array}{l}\text { Second } \\
\text { group }\end{array}$ & 62.00 & & & 2.63 \\
\hline & & & $\begin{array}{l}\text { Third } \\
\text { group }\end{array}$ & 64.63 & & & \\
\hline \multirow{3}{*}{\multicolumn{2}{|c|}{$\begin{array}{c}\text { The level record of } \\
\text { javelin throw }\end{array}$}} & \multirow[t]{3}{*}{$\mathrm{M}$} & $\begin{array}{l}\text { First } \\
\text { group }\end{array}$ & 25.54 & & 2.49 & 4.91 \\
\hline & & & $\begin{array}{l}\text { Second } \\
\text { group }\end{array}$ & 28.03 & & & 2.42 \\
\hline & & & $\begin{array}{l}\text { Third } \\
\text { group }\end{array}$ & 30.45 & & & \\
\hline
\end{tabular}

(*) means that there are statistical significant differences between the two groups at significance level0,05

Discussion:

In the light of the results of the statistical analysis, within the sample and the results of the used measurements and through the research objectives, the researcher was able to discuss the results as follows:

Table (4) shows that there are statistically significant differences between the average of the pre and post measurements of the first experimental group in measuring the grip strength and the level record of the javelin throw "under consideration" and in the direction of the post measurement. The researcher attributed this to the effect of the experimental variable, which has a positive effect on the improvement of grip

Assiut Journal For Sport Science Arts 
strength and thus improve the level record accordingly.

This agrees with the study of both Michael Anderson and Mark Anderson (2015) (11) which indicated that the Finger strength improved an average of $21.5 \%$ after only 4 weeks of training, and overall climbing ability improved an average of 2.5 Yosemite.

Thus, the validity of the first hypothesis, which provides that there are statistically significant differences between the pre and post measurements of the grip strength and the level record of the first experimental group $(10 \mathrm{~kg})$ in favor of the post measurement.

Table (5) show that there are statistically significant differences between the average of the pre and post measurements of the second experimental group in measuring the grip strength and the level record of the javelin throw "under consideration" and in the direction of the post measurement.

The researcher attributed that to the use of finger-grip exercises to develop the grip strength; thus it affected on the improving the level record, which had an evident positive effect in the post measurements.

The javelin throw movements are uniform movements from the first step at the beginning of the run to the movement of the fingers extend in the movement of throwing(15: 232).

Thus, the validity of the second hypothesis, which provides that there are statistically significant differences between the pre and post measurements of the grip strength and the level record of the first experimental group $(20 \mathrm{~kg})$ in favor of the post measurement.

Table (6) show that there are statistically significant differences between the average of the pre and post measurements of the third experimental group in measuring the grip strength and the level record of the javelin throw "under consideration" and in the direction of the post measurement.

The researcher attributed that to the positive effective of finger-grip through the weighted fingers, which trained the third group with a weight of $30 \mathrm{~g}$.

This agrees with the study of " Fayza Mohammed" 
(2008) (4), which pointed out that the use of weighted fingers as a method of training in basketball lead to increase and improve the proportion of correct shooting, as well as raise the level of dribbling and scrolling, double the strength of fingers, wrist and palm hand in general and help the strength Flexibility and bearing fingers which will improve these skills Thus, the validity of the third hypothesis, which provides that there are statistically significant differences between the pre and post measurements of the grip strength and the level record of the first experimental group $(30 \mathrm{~kg})$ in favor of the post measurement.

Table (7) (8) shows that there were statistically significant differences between the three experimental groups in measuring the grip strength and the level record of the javelin throw" under consideration" and in the direction of the third one.

The researcher attributed this to the fact that the weighted fingers used by the third group, which was trained with a weight of (30g) per finger was better than the weight $(10,20) \mathrm{g}$ per finger, which trained the first and second experimental group.

This is consistent with the study of Mounir Mustafa and Susan Hosny (2005), ( 12 )which indicated that weighted finger straining leads to increasing the finger strength of the player, thus improving the efficiency and speed of the hand response and its dynamic performance, and it gives more positive results than the traditional methods in developing elements Fitness "as speed, ability, agility and compatibility" and also improve some of the offensive skills in basketball.

As indicated a study Cronin, J, Lawton, T, Harris, $\mathrm{N}$, Kilding, A, and McMaster, DT (2017) (2) There is a relationship between handgrip strength and sports performance

Thus, the validity of the forth hypothesis, which provides that there are statistically significant differences between the post measurements of the grip strength and the level record of the three experimental groups in favor of the third one.

Table (4) (5) (6) shows that there are differences in the rates of change between the 
mean of the pre and post measurements of the experimental groups (1), (2) and (3) in measuring the grip strength and the level record of javelin throw for the members of research sample. The researcher attributes the rate of improvement in the post measurements than the pre ones of all groups to the regularity in weighted finger exercises.

This is in line with the study of Mounir Mustafa and Susan Husni (2005) and Fayza Mohammed (2008), where they pointed out that strengthening finger training led to an improvement in both the physical elements and some of the basketball offensive skills of the post measurements that the pre ones.

Thus, the validity of the five hypothesis, which provides that there are statistically significant differences between the rates of change between the pre and post measurements of the three experimental groups (1), (2), (3) in measuring the strength of the grip and the level record of javelin throw for the members of the research sample

Conclusions :
1. The use of weighted finger exercises have a positive effect on grip strength, the mean Pre measurement of the Right grip strength $(58.00 \mathrm{~kg})$ and Left grip strength $(57.88 \mathrm{~kg})$, while the mean Post measurement of the Right grip strength (58.88 $\mathrm{kg}$ ) and Left grip strength (58.75.) for the first experimental group (10 g), while the mean Pre measurements of the Right grip strength $(62.25 \mathrm{~kg})$ and the Left grip strength $(62.00 \mathrm{~kg})$. For the second experimental group (20 g), while the mean Pre measurement of the right grip strength $(58.25 \mathrm{~kg})$ And the Left grip strength (58.88 $\mathrm{kg}$ ) while the mean Post measurement of the right grip strength $(65.50 \mathrm{~kg})$ and the Left grip strength $(64.63 \mathrm{~kg})$ for the third experimental group (30 g)

2 . The use of weighted finger exercises have a positive effect on the level record of the javelin throw competition athletics, the mean Pre measurement $(25.24$

meters), while it was Post measurement (25.54 meters) for the first experimental group $(10 \mathrm{~g})$, while the mean Pre measurement (26.64 meters) and the mean of the post 
measurement $(28.03 \mathrm{~m})$ for the second experimental group (20 g), while the mean Pre measurement $(26.78 \mathrm{~m})$ and the mean of the post measurement $(30.45 \mathrm{~m})$ for the third experimental group $(30 \mathrm{~g})$.

3 . Using weight bearing rings with $(30 \mathrm{~g})$ was better than with $(10,20) \mathrm{g}$.

References:

1- Abdul- Aziz Al- Nimr, Nariman Khatib: weighted training "design of force programs and planning the training season, Book Center for Publishing, Cairo, 1996.

2- Cronin, J, Lawton, T, Harris, N, Kilding, A, and McMaster, DT: A brief review of handgrip strength and sport performance, $\mathbf{J}$ Strength Cond, 2017; 31(11): 3187-3217.

\section{3- Due-Ping Chen, You-Mei}

Lu: Intervention study of finger-movement exercises and finger weight-lift training for improvement of handgrip strength among the very elderly, international journal of- nursing sciences ,2014 ; 2352 (0132) : 165-170.

4- Fayza Mohammed AlSayed Ahmed: Effect of a weighted-finger program to develop some offensive skills In basketball, unpublished master thesis, Faculty of Physical Education for Girls, Zagazig University , 2008.

\section{Gada Ahmed Ibrahim}

Zeater: The Effect of using coordination abilities Drills of Javelin Throw on achievement level feamale students at faculty of Physical Education , master thesis ,Faculty of Physical Education Minia University, 2008.

\section{Ghada Galal Abdel}

Hakim: Effect of training program on light hand weights in walking and running on efficiency Physical work for students of the Faculty of Physical Education, unpublished $\mathrm{PhD}$ thesis, Faculty of Physical Education for Girls, Helwan University, 1998 .

\section{Hamid Abdul Nabi Abdul} Kadhim, Amira Mohammed Adham: Special power and influence in the completion of Javelin for the beginner, Magazine of Physical Education , 2007; 17 (2). 238256

8. Hamdi Al-Sayed AbdelHamid Al-Nawaziri : Effect of compound- training on muscular balance for leg muscles and side deviations and record level for javelin 
throw athletics, Doctor thesis ,Faculty of Physical Education Mansoura University, cairo ,Egypt, 2016.

9. Ja'far Husein Ali: The Effect of a Suggested Training Method to Improve the Explosive Power of Active Muscles in Javelin , JOURNAL OF SPORT SCIENCES,2012;4(2),

10. Khairia Ibrahim AlSakar, Sulaiman Ali Hassan: Guide to Education and Training in Shooting competitions, Dar Al Ma'arif, Alexandria, 1997.

11. Michael Anderson and Mark Anderson: A novel tool and training methodology for improving finger strength in rock climbers, Procedia Engineering,7th Asia-Pacific Congress on Sports Technology, 2015; (112) 491 496.

12. Mounir Mustafa Abdeen, Sawsan Hosny Mahmoud : The Effect of Using weighted Fingers on Learning
Some Offensive skills in basketball, Journal of the Faculty of Physical Education Mansoura University, 2005; 5.127-163

\section{3- Nabila Ahmed Abdel} Rahman, et al: Field and track competitions for the girls, first part jump and throw", El Faneya For Printing \& Publishing, Alexandria, 1990.

\section{4- Ra'id Al-Ragad:}

Relationship of Physical Characters and Anthropometric Measurement and Performance of Javelin throwing Event, Journal of An- Najah University for Research (Humanities), 2010; 24 $263-279$.

\section{5- Tamer Gamal Ibrahim :} Effect of various weight training exercises for the development of speed characteristics For basketball players "unpublished master thesis", Faculty of Physical Education for Boys, Helwan University, 2001. 